Article

\title{
The Problem of Realist Events in American Journalism
}

\author{
Kevin G. Barnhurst \\ School of Media and Communication, University of Leeds, Woodhouse Lane, LS2 9JT Leeds, UK; \\ E-Mail: k.barnhurst@leeds.ac.uk; Tel.: +44-113-343-8859; Fax: +44-113-343-5808
}

Submitted: 17 August 2014 | Accepted: 24 September 2014 | Published: 17 October 2014

\begin{abstract}
Since the nineteenth century, more kinds of news outlets and ways of presenting news grew along with telegraphic, telephonic, and digital communications, leading journalists, policymakers, and critics to assume that more events became available than ever before. Attentive audiences say in surveys that they feel overloaded with information, and journalists tend to agree. Although news seems to have become more focused on events, several studies analyzing U.S. news content for the past century and a half show that journalists have been including fewer events within their coverage. In newspapers the events in stories declined over the twentieth century, and national newscasts decreased the share of event coverage since 1968 on television and since 1980 on public radio. Mainstream news websites continued the trend through the 2000s. Instead of providing access to more of the "what", journalists moved from event-centered to meaning-centered news, still claiming to give a factual account in their stories, built on a foundation of American realism. As journalists concentrated on fewer and bigger events to compete, audiences turned away from mainstream news to look for what seems like an abundance of events in digital media.
\end{abstract}

\section{Keywords}

content analysis; cultural critique; five Ws; history; journalism; media studies; news; realism; social constructionism

\section{Issue}

This article is part of a regular issue of Media and Communication, edited by Professor Bradley Greenberg (Michigan State University, USA) and Professor Elisabeth Klaus (University of Salzburg, Austria).

(C) 2014 by the author; licensee Cogitatio (Lisbon, Portugal). This article is licensed under a Creative Commons Attribution 4.0 International License (CC BY).

\section{Introduction}

When famed muckraker Will Irwin assessed American journalism a century ago, thousands of events entered the flow of news, but, he says with confidence, "information on most of them reaches the newspaper offices" (Irwin, 1969, p. 34). Fifty years later a Peoria (Illinois) Star editor reported receiving twelve thousand inches of wire copy a week, and gatekeeping became the metaphor for what he and other journalists do to manage the flow (White, 1950; see also Reese \& Ballinger, 2001). Over the century, the reach of news organizations grew, and wire services built networks that circled the planet. Although some foreign bureaus began to shrink later on, the modes of communication multiplied beyond radio and television, to cable and satellite TV, and research suggests that television news has become more focused on events (lyengar, 1991). The conveyances for news expanded from telegraph, telephone trunk cables, air couriers, and fax and teletype machines to computer and wireless devices. With internet and cellular telecommunications, reporters seem to have access to even more events. The expanding ways and means-the growing reach-of newsgathering suggests a commonsense assumption: that audiences can also get access to more news events than ever before.

Are more events covered now than a century-or even fifty years-ago? Journalists say a deluge of occurrences has become a "glut" they must govern. A veteran beat reporter who worked for the Sacramento Bee and Baltimore Sun laments having "too many stories, too little time" (Winburn, 2003, p. 114). "We are all flooded with too much information", an ex-Newsday reporter says. "People are intellectually and emotionally capable of absorbing only so much" (Rosenblum, 1981, p. 14; cf. Rosenblum, 1993). During the financial 
meltdown of 2008, journalists quoted audience members unable to "keep up anymore with all of the news and current events" (Williams, 2008, October 10).

Public opinion polls consistently find that about a third of U.S. Americans - those who most attend to news-feel overloaded (Pew Research Center, 2006, July 30), and despite ups and downs, the glut of events continues to cause stress as crises come and go (Fuller, 2010). Almost two-thirds of U.S. professional or whitecollar workers in 2008 and 2010 said that having too much information slows their work (Walsh \& Vivons, 2010, October 20). There seem to be too many news events especially for the young (Nordenson, 2008). The "relentless rise in the number of news outlets, the frequency of news reports, and the media's clamor for every scrap of new information", says former New York Times editor Jack Rosenthal, has immersed society "in a flood" that creates "a kind of widespread attention deficit disorder" (2004, August 8). Consequences follow because the belief that an information overload exists has led journalists and others to take action.

\section{The Press: Events Dwindled in Stories}

How do journalists cover all those events? To find out, several studies have examined newspaper content for more than a century. They showed that the form and content of the news changed, leaving room for fewer stories, and those remaining grew notably longer (Barnhurst \& Nerone, 2001). The declining number of articles and items on the front page need not imply that fewer events get reported. For instance, longer stories might include more events. A century ago newspapers would run three reports on three different fires in the city, but an editor could combine all three into one package. Or a reporter might write one story built around a similarity that the three events share. Did that happen? No, news stories included fewer events through the twentieth century (Figure 1).

The number per article declined markedly across newspapers (Barnhurst and Mutz, 1997). Two large papers, the New York Times and Chicago Tribune, moved strongly away from multiple events, and the trend was solid at the smaller Portland Oregonian. News topics also followed the trend. Events in crime stories changed the least, but accident stories included fewer events, and the number in employment stories declined sharply. The consistency for newspapers and topics indicates something more than a simple regrouping of events: Journalists became more selective. A typical reporter once covered half a dozen stories in a day, but that number dwindled to a few or even less. And editors, instead of running a roundup of several fires that day or week, would publish only the biggest (if they included any at all). One of the fires might become an example, representing all the fires of that sort, and the longer story might then focus on firerelated issues, but not on individual events.

The biggest downturn occurred between 1894 and the beginning of World War I, a period of turmoil in Europe that produced large numbers of news events. As the pressures from all those occurrences increased and the means for transmitting them expanded, journalists made fewer of them into news and published lengthier stories. They also began to publish interviews (Fishman, 1980; Schudson, 2001), a shocking departure that created an event at the behest of editors and under the control of reporters.

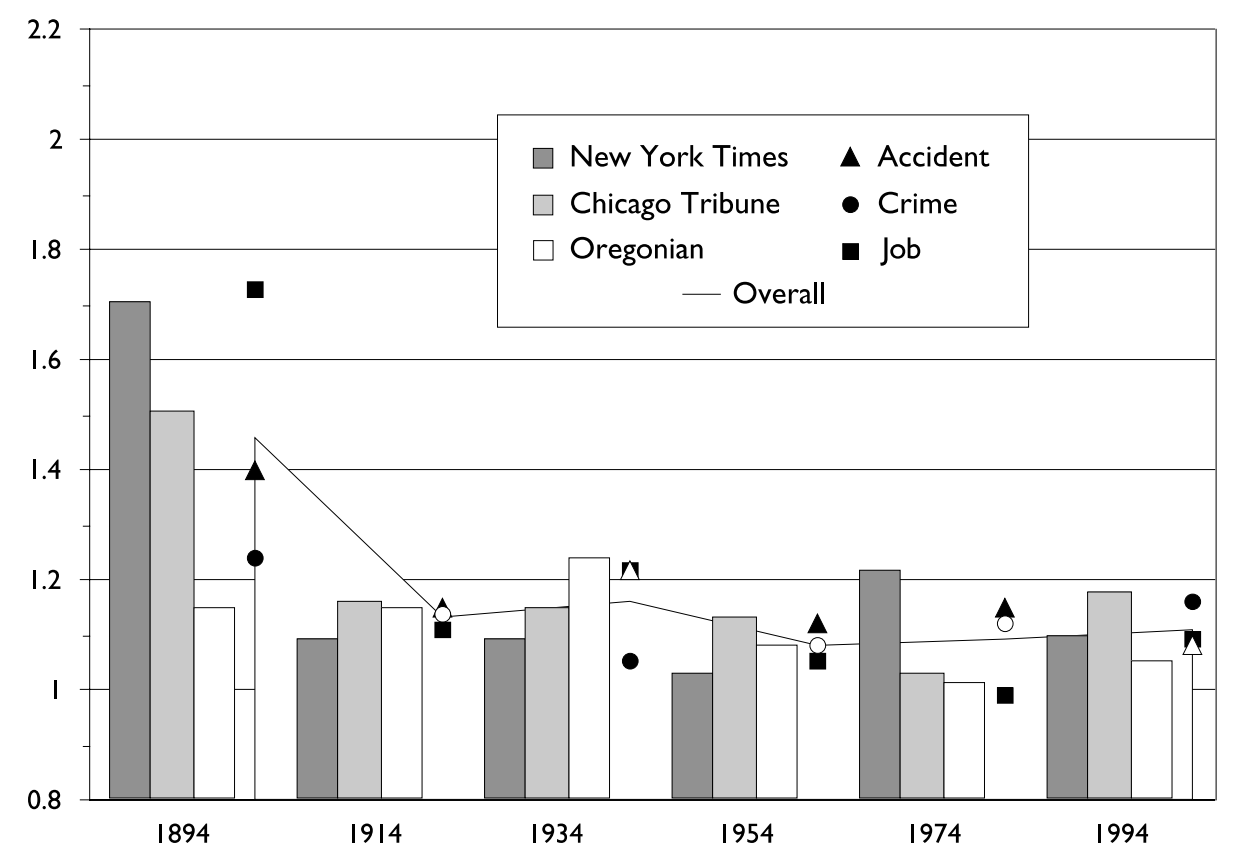

Figure 1. Fewer news events. Number of events in an average newspaper story. Source: Barnhurst and Mutz (1997). 
In the wake of the change, a wide critique of the press took place. In the first instance, Irwin published a fifteen-part series on American journalism in Collier's, a weekly magazine leading progressive reforms. The 1911 series sought to extend progressive thinking to journalism. The problem Irwin cites is slanted news. "Newspapers...have come more and more to put their views into their news columns" (Irwin, 1969, p. 8). He saw reporters coming under pressure from advertisers, corporate buyouts, and the tendency of publishers to join the country club set. "Most news is not fact anyway", he writes, quoting a popular quip. "It is gossip about facts" (Irwin, 1969, p. 36). In the last installment of the series, he proposes a solution: event-centered news, stripped of opinion. World War I made the need for straight news even more urgent (Feldman, 2008). The Brass Check, Upton Sinclair's best-selling 1920 attack on the press, calls the newspaper a mental "munitions factory" building the "bombs and gas-shells" (Sinclair, 1936, p. 412) to impose ideas on and instill fear among the people. His solution challenges newspapers to be "a record of events pure and simple" (quoted in Goldstein, 1989, p. 157).

The following year Walter Lippmann, a founding dean among intellectual columnists, and Charles Merz, who became editorial page editor of the New York Times, published "A Test of News" in The New Republic. Examining three years of Times stories on the Russian Revolution, they call the coverage "nothing short of a disaster" (Lippmann \& Merz, 1920, August 4, pp. 23). The Times had reported news events that never happened, and other headlines and captions emphasized unsupported and unsupportable interpretations. How, they ask, did such systematic misrepresentations occur? Wishing for a favorable outcome to the war, the paper published "semi-editorial news dispatches", write Lippmann and Merz, and so "a great people in a supreme crisis could not secure the minimum of necessary information on a supremely important event" (1920, p. 3).

Others agreed. In the January 1922 Atlantic Monthly, magazine journalist Frederick Lewis Allen, having witnessed censorship, propaganda, and "controlling or doctoring the news" during World War I, writes: "it is immensely important that the press shall give us the facts straight" (Allen, 1922, p. 44). The public was becoming aware that the German, British, and even U.S. governments had mounted propaganda efforts within the United States. The Committee on Public Information had circulated handouts, publicity materials, and exhibits, and its system of speakers and committees blanketed the country to solidify pro-war public opinion and whip up feeling against the enemy (Mock \& Larson, 1968; Sproule, 1987). Scholars led the reaction, developing propaganda analysis to study social control in modern societies, and then spreading results widely in popular media. Schools, colleges, and adult education centers received study materials of the Institute for Propaganda Analysis from Columbia University. Analysts aimed to arm citizens against future effortsfrom covert, intentional propaganda to overt or intentional influence-to slant the news.

In the decades following their critiques, the number of events covered in the average report appearing in the New York Times and other newspapers increased slightly and event-centered reporting advanced. But the average then fell again after 1934, a second downturn that occurred as alarms about propaganda gave way to fears that bare-bones information could become misleading. Facing the Great Depression and World War II, first United Press and then the Associated Press (Mott, 1952) pioneered news that shifted away from the "what" to the "why" of news, on the belief that attentive citizens felt overwhelmed and needed journalists to explain events.

By midcentury, political crisis and the rise of television prompted critiques of event-centered news. Beginning in 1947, the Newspaper Guild hosted key journalists' speeches on the dangers of reporting mere events. The series began with editors of the New York Times, St. Louis Post-Dispatch, and New York WorldTelegram and had a theme: "The press...put before the reader a confusing welter of facts, [so that] vital issues were not interrelated and interpreted in understandable form" (Casey, 1963, xi).

One way to understand the changes in news events is through a model from science. Thomas Kuhn's The Structure of Scientific Revolutions (1996) says that craft-based knowledge forms a paradigm, a lens to see the world. When the paradigm enters crisis, scientists begin making new rules, which sometimes produces a new paradigm in what Kuhn calls a scientific revolution. Journalists, like scientists, learn their craft through action. Their laboratory is the police station, White House, or street. When news work enters crisis, journalists begin rulemaking, as they did in the nineteenthcentury shift from the partisan-literary paradigm. The Great War debacle and the Crash and Great Depression helped complete the shift to modern realist journalism, which accepts rules that focus coverage on what happens, verifies facts, and demarcates news from opinion. Chronicling occurrences at first seemed the best lens for making sense of the world.

Nineteenth-century journalists resembled naturalists, who gathered unique specimens that seemed to provide an understanding of the world through storytelling. But the means soon overtook the ends (Vaihinger, 1968), because so many occurrences seemed to overwhelm the goal of describing the world. The new realist paradigm brought into focus the sorting of what happened into categories. Work processes, from covering beats to competing with other journalists, generated a set of mental tools called rubrics, such as relying on social types. Rubrics grow out of necessity when cultural 
producers work under pressure, as when journalists call up known protagonists and antagonists to generate a story quickly. Journalism has produced many other types, fictional constructs necessary to practical work: the individual (as audience member or source), for example, versus a group, or a person-on-the-street versus someone in an official role, or a generic U.S. American versus someone defined by a local identity (New Yorker, Texan). Some are stereotypes for work (a bricklayer, a priest) or are stand-ins (the President for the U.S. Federal government). Others are grander: democracy, freedom.

Journalists classified events using rubrics that led them away from event-centered news and toward making broader judgments. Editors can make ethical choices based on a mental picture of the audience consuming news while sitting together as a family at breakfast. Faced with difficult editorial decisions, editors can call up their audience picture to counterbalance pressures they feel from other editors and the market. The picture is a useful shortcut despite being inaccurate, and so journalism employs the philosophy of as if (Vaihinger, 1968), relying on abstract types because of their helpfulness, not their truth. As journalists make the news every day, they produce a reality without considering the real. In the classic description (Molotch \& Lester, 1974), a journalist encounters a plethora of occurrences, natural to the world out there and a potential resource. The job is to elevate occurrences, through set procedures, to the status of events. Events are useful occurrences, and journalists become skilled at identifying usefulness. Politicians' news conferences and parties' conventions serve their own uses, which journalists view with skepticism. Informants pursue their own uses for any scandal that grows from occurrences they reveal. Politicians, informers, and others pursue their own ends, but journalists find unintentional occurrences more useful, especially the accidental or serendipitous. Chance occurrences most lend themselves to journalism. These uses make journalists appear rational, competent, and original as practitioners, the same ends that the news industry supports and rewards.

News useful to journalists matters because information "does not merely go to publics, it creates them" (Molotch \& Lester, 1974, p. 101). A public takes shape in the process of forming events from the raw material of many occurrences (Dewey, 1927). When reporting sticks to events, it describes a society in consensus. Event-centered reporting may signal consensus, or at least the suppression of disagreement. The shifts toward event coverage in the early twentieth century reflected the growing U.S. social consensus that reached a midcentury peak.

When groups promoting an occurrence come into conflict, the contentions define an event as an issue. Issues have ready-made usefulness for reporters to convey each side's arguments. The news organization itself then takes the middle ground, as rational mediator. When identifying issues, journalists unintentionally sow disharmony. The opposing sides appear irrational while journalists appear un-tendentious themselves.

After midcentury, as news moved away from eventcentered coverage, the news paradigm evolved within the reality "out there" for journalists to observe and describe. The technologies of everyday life shifted as television emerged. What happened to broadcast news?

\section{TV and NPR Radio: Events Also Waned in Broadcast News}

The McCarthy hearings solidified thinking against event-centered news. Sen. Joseph R. McCarthy's accusations that the Truman Administration was harboring Communists brought $A B C$ Television into national prominence, riveting national attention with live proceedings. Elmer Davis, who had left reporting for the New York Times to become a commentator on CBS Radio, challenged journalism conventions, saying "the best papers in the country gave their readers...a seriously mistaken impression" by paying attention to "proven liars" and imposing a "burden on the reader" (quoted in Casey, 1963, pp. 57, 61). His solution is a "mixture of news and interpretation" that can "explain the news for the customer" (1963, pp. 63-64), the emerging tendency in journalism. Other prominent broadcasters took up his critique. In his lecture, Eric Sevareid of CBS News observes "the enormous flood of facts" and finds journalists "not really preparing the American mind" (quoted in Casey, 1963, p. 79). He calls "the unpardonable sin of the present" a kind of "superficiality", with a "lack of depth", and an "absence of perspective" (quoted in Casey, 1963, p. 91). Press historian Frank Luther Mott also calls the processes "looming up as background" far more important "than most of the thousand little happenings...that fill so many newspaper columns" (Mott, 1952, p. 31). Other researchers at mid century shared Mott's view (see Griffith, 1987).

Broadcast news in its early decades continued the trends found in print. The press reduced event coverage more in the second half of the century. One way to measure broadcast events is simply by counting the number of stories in the average show. A thirty-year analysis of $A B C, C B S$, and $N B C$ evening news found a consistent trend on all three networks toward fewer items per show each year (Riffe \& Budianto, 2001). A later industry study suggested a rebound (PEJ, 2006), but the number of stories gives an incomplete picture of the programs.

Another way to examine event coverage is by looking inside each story to take stock (Steele \& Barnhurst, 1996). How often were journalists giving information about current events? In their voice-overs, stand-ups, and other speech, television journalists shifted away 
from the "what" of reporting (Figure 2). In 1968 they stuck to information a third of the times they spoke, but the share declined over the next two decades. The share went up and down in the four-year intervals between national elections, but the trend was downward. As they became less involved in basic information, television journalists spent more time offering opinions, showing agreement, and voicing reactions.

National Public Radio (NPR) news followed the same trend, without the same pressures from market competition and advertising (Barnhurst, 2003). From the 1980 election - the first when Morning Edition and afternoon All Things Considered were both on the airNPR journalists stuck to information of events about half the times they spoke. But then the share dropped to nearly a third. To illustrate, an October 13, 1980, campaign story includes four utterances, two each totaling 19 seconds of Correspondent Linda Wertheimer and 55 seconds of President Jimmy Carter. Wertheimer opens by focusing on what happened when Carter faced hecklers at a community center. The package was straight event coverage, with terms implying a judgment coming only from the candidate. But in an October 17, 1996, report, Correspondent Joanne Silberner speaks more often and longer than candidate Bill Clinton. She opens her story with a personal exclamation and then expresses her judgment about the Clinton health care proposals. The archetypal activityreporting what was happening-declined during the NPR political coverage.

Journalists and journalism histories tell a different story, how event-centered television news grabbed breaking news from newspapers (Donovan \& Scherer,
1992). But national television and serious radio news followed the trends of the mainstream press, focusing less on information about events. Critics say that journalism should do more than cover events alone (e.g., Alterman, 2003) and say that especially television news should give more context (Gitlin, 1987). Research suggests the preponderance of network news is episodic rather than thematic, focused narrowly on specific events rather than on the circumstances behind them (lyengar, 1991). Episodic news leaves viewers struggling to attribute political responsibility when important issues arise, and the pattern has held for decades (Feinberg, 2009).

A century ago Progressives proposed that straightforward reporting of what happens will change the world. A century later conservatives resist change by arguing for just-the-facts journalism (e.g., Ranney, 1983). The political reversal is dramatic. But progressive and conservative viewpoints of journalism are not at opposite poles. Beneath the two positions is a shared belief in a concrete reality open to observation and description. Both sides argue from a realist perspective. Modern journalism emerged as a literary activity in the nineteenth century, along with the modern novel (Hellmann, 1981), and the two kinds of writing relied on realism. For realists, all writers and their audiences have access to the concrete world, but journalists, unlike most novelists and readers, have a privileged vantage point. They focus on documenting reality full time and have routine contacts with sources who themselves observe reality. The efforts of journalists day after day build a comprehensive picture of reality, so that knowledge of the world accumulates, they say.

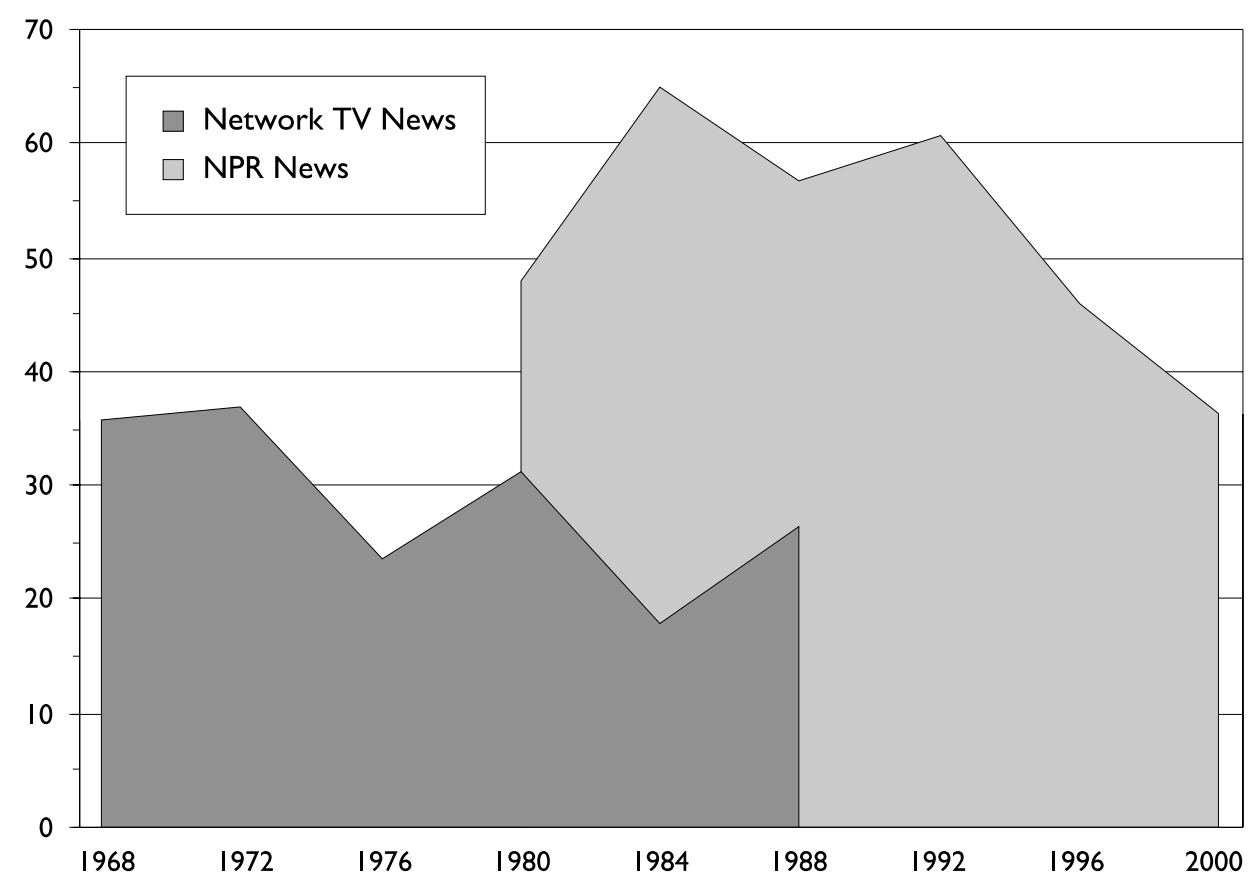

Figure 2. Less focus on information. Percentage of speech acts journalists used to give information about events. Source: Steele and Barnhurst (1996); Barnhurst (2003). 
After the advent of broadcasting, the paradigm of realist news entered a new phase, where making meaning added value to coverage and journalists found that events indicated trends and issues (e.g., Boyle \& Hoeschen, 2001). The job of journalism began to require a better lens for viewing what happens. Realism saw mere facts as misleading, and a standard for quality news became how well it could make events understandable. In contrast to the consensus society of event coverage, issue coverage describes a society in conflict. Issue-centered reporting may signal honest disagreement or something less hopeful, a basic contentiousness. Either way journalism helps create those meanings. The shift in realist news toward sensemaking grew throughout the second half of the century, as race, abortion, gender, and other disputes polarized U.S. politics, and reached its height in the dispute over the meaning of the Watergate burglary. Over the century, first issue coverage and then partisan reporting increased, helping solidify the most intractable issues of U.S. society.

News operates to reflect and to focus, shining the light "out there" but focusing it with potential hazard. Journalists who stick to events face censure for ignoring the context and common sense. But when journalists make sense of events, they face censure for claiming too much say over what matters or for taking sides in politics. But journalists have gained ground either way, adding economic and social status through both phases of the realist news paradigm (Barnhurst, 2010). Their turn to realist fact early in the twentieth century made them stronger observers, neutral arbiters unsullied by politics, a position publishers found desirable for expanding market share (Barnhurst \& Nerone, 2001). And journalists' turn to realist investigation and explanation lifted them even higher in public esteem as the profession reached its zenith around the 1970s.

When journalists justify their work, they employ not realism but other terms for their aims: facts and truth. They have practical definitions for both terms. Although journalists talk about events and facts almost interchangeably, facts are the larger item (White, 1970). Reporting facts carries a heavier burden than reporting events because factual coverage requires a journalist to say how the world is, and not just what happened in it. The first challenge when selecting and arraying events is to reveal facts. Journalists judge event reporting by whether it sticks to facts, and that means they try to align new occurrences with the accumulated experience of previous reporting.

Practical success with facts drives reporting toward a larger goal: the truth. Truth is the highest aim and justification of the newer journalism (e.g., Sevareid quoted in Casey, 1963). What works is what produces events that match the facts, but what works best is the producing of events that align those facts with understanding the wider world. As journalists critique each other-and as they join in the process of individual and then group innovation-they define truth by what has worked or failed in the effort to view the world. Journalists glean that worldview from the culture surrounding them, but a worldview that works tends to produce more facts, especially reliable and useful ones. Journalists judge others by the same standard. Competing political parties make conflicting assertions about what an occurrence means and advertise different claims using facts to show what candidates stand for. Journalists then do "truth-squad" stories, asking whether a statement squares with what the world is like. A claim about or an image of an event is true if it corresponds to the facts.

The job of reporting events generates a conjecture about the world (giving events their initial meaning), and through repeated event coverage-and through the resolution of issues - the guesses about things settle into established facts. Slowly knowledge of the world accumulates, a realist would say, in the form of a journalism truth, which amounts to a broader statement that corresponds to the array of facts. When new occurrences fail to fit into the meanings available for events, journalism adjusts through discussion and through trial and error. So journalists confronting the propaganda of World War I had to refocus on events, and the McCarthy hearings refocused news on the need to stand apart from occurrences and instead to emphasize issues. Both moves attempted to realign journalism with facts and truth.

Scientists also generate conjectures about the world and repeat their work in a process called replication. The efforts confirm a larger picture of the world, the paradigms they judge by "their heuristic power: how many new facts did they produce?" (Lakatos, 1974, 137). The processes are parallel for scientists and journalists, who attend to occurrences out there, formulating guesses that become either "events" or "hypotheses." Both resolve issues to arrive at facts, and both seek to establish a larger reality as "truth."

By the twenty-first century, realism came under doubt as audiences fragmented and U.S. intellectual life entered ferment. What worked in the 1970s no longer worked in the changing networked world since the 1990s. To understand the new paradigm emerging by the century's end requires a look at how the realist stock in trade of journalism fared in the digital era.

\section{Online News: "Realism" about Events Persisted Online}

Pulitzer prizewinner Alex Jones says that U.S. journalism ran into trouble because new technologies produce not facts but unreality (quoted in Shafer, 2009, August 27). Newer venues for news seem to blur the line "between real reporting and faking it," a former political reporter says (Mears, 2009, p. 424). "The risk is that readers and viewers-voters-won't be able to sepa- 
rate reported fact from fabricated fiction." How did the "what" of news fare online?

Mainstream news outlets, including NYTimes.com, ChicagoTribune.com, and OregonLive.com, went through a period of experimentation online (Figure 3 ). Politics, crime, accident, and employment stories began the first decade of the 2000s by reporting more events, reversing decades of declines (Barnhurst, 2010). By 2005 they added even more events to stories, but the news sites diverged, with OregonLive.com focusing on the most events (Barnhurst, 2013). Surveys also found the number and depth of news reports decreasing as more online outlets emerged (PEJ, 2006; Rainey, 2006, March 13). U.S. journalism online was in state of ferment, but why? Journalists at the time pointed to new technology (Regan, 2000), although new media produced little revenue. Publishers invested in web editions only as necessary to block rival sites and hardly used the interactive potential of the internet (Barnhurst, 2002). Although publishers resisted new technology, journalists responded to the idea of linking events together by doing online fact-checking (Ross, 1998), so that references to events within stories increased.

But by 2010 current events declined to the levels of the 1990s (Barnhurst, 2012). The "what" of news returned to earlier patterns, as journalists began retrenching and the news outlets moved again in lockstep. The reemerging patterns suggest a missed opportunity. Journalists might have continued pursuing a linked perspective on what happens in news, rejecting the constraints of realism. Their readers were using interconnectivity to cope with the flow of information in the new century, a third of them sharing news stories on social media, half relying word of mouth, and 80 percent using e-mail links (Purcell, Rainie, Mitchell, Rosenstiel, \& Olmstead, 2010, March 1). Instead of keeping up with public habits, journalists pushed back, closing ranks around a journalist's kind of truth.

Journalists and researchers in journalism studies lamented the downsizing, financial turmoil, and competitive pressures the industry faced in the new era. But few questioned the realism behind journalists' pursuit of facts and truth. The reading public began shifting to a new regime of "what-ness," not abandoning news but finding it through aggregators, opinion blogs, and other go-between venues for recycled news content. Their move raises questions about once-common beliefs in the tenets of "quality" news offering firsthand evidence, journalists as witnesses, and the value of the neutral account. Journalists themselves helped usher in the new consensus by moving from eventcentered to meaning-centered news. As the face-toface and media experiences of audiences merged, so that "friending" and "informing" crossed almost seamlessly between online and embodied modes of contact, audiences and users found new lenses for viewing the world. Journalists at first experimented and then pulled back, returning to the familiar ground of facts and truth.

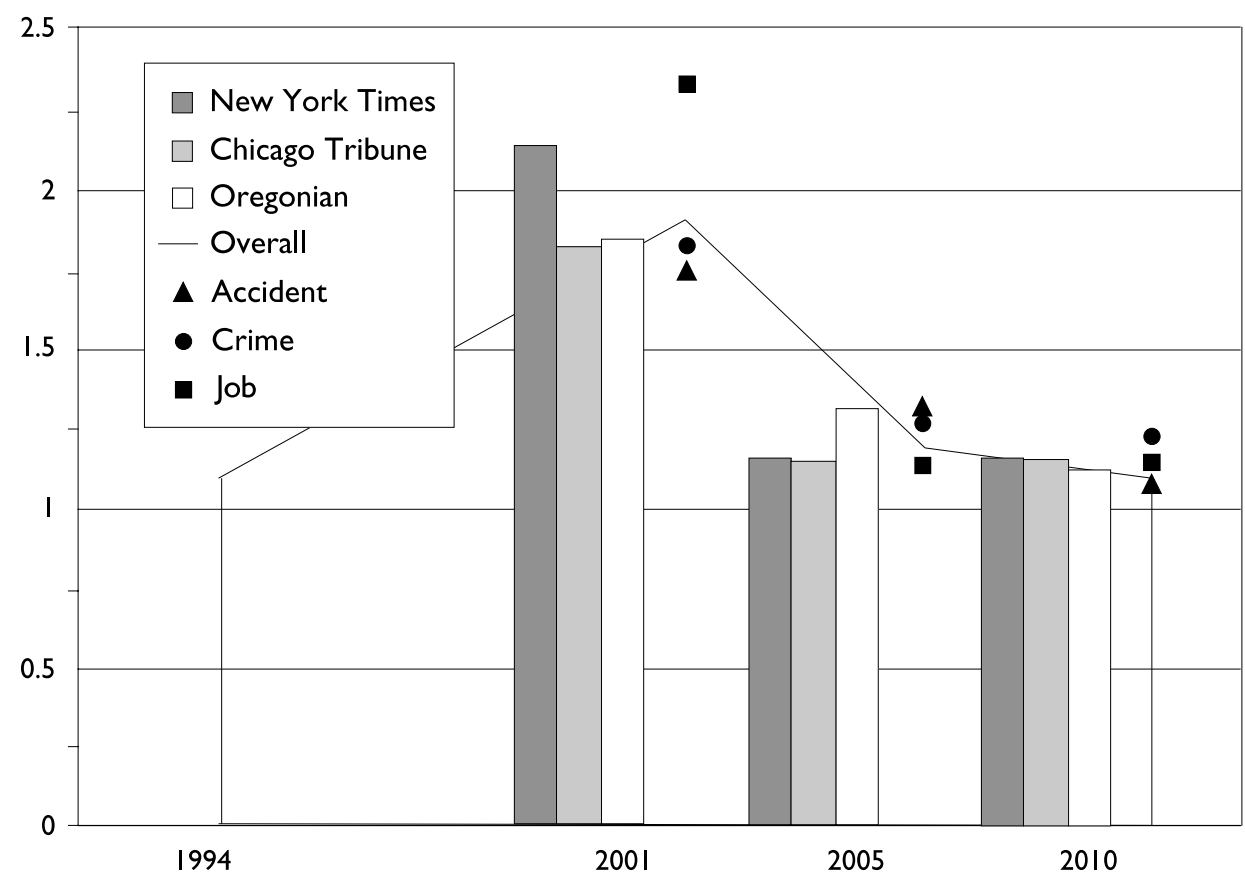

Figure 3. Events spike online. Number of events for online news stories compared to the prior number for print. Sources: Barnhurst \& Mutz (1997); Barnhurst (2010, 2012, 2013). 
Professional claims to factual truth have come into question in the twenty-first century. In the prevalent view, facts have two qualities: they are independent of what individuals may think about them, and they are stable in meaning over time. Together the qualities establish a view that philosophers call naive realism (or naïve empiricism). Naïve realism assumes the existence of "events out there to be observed and appropriately described" (Mulkay, 1979, p. 35). But there are two problems with the standard of realism, and they reside, not surprisingly, in the processes of observing and describing. What does it mean to observe? Reporters sometimes go out on the streets to witness occurrences, but they can see only what happens within their range of vision. Other occurrences fall outside what reporters can observe. Interviews make the idea of observing less concrete because journalists select among sources, make the interview happen, and select questions. Does an interview by telephone without any other occurrences and physical cues count as observing? When rewriting wire stories with a local angle, are journalists observing?

"Observation involves the application of categories to sense impression" (Mulkay, 1979, p. 46). Classifying things (or persons and their states of being and doing) is an act of interpretation, and interpretations grow from expectations. What researchers and journalists want to see can color their perceptions and reporting, and so observing has a key limitation. As in the 1920s case of Russian Revolution coverage, in the 2000s the New York Times reported not observations about the build-up for U.S. invasion of Iraq but what officials providing information wanted to be true, and the prowar stories got more dramatic play, just as did stories leading up to World War I. Unlike the earlier case, the Times editors a century later recanted, citing the "strong desire" of sources, the eagerness of Bush Administration officials, and reporters "too intent on rushing scoops into the paper" (New York Times, May $26,2004)$. The large errors of judgment underline a limitation of reporting, because even if journalists cover only what they themselves witness, observation still involves interpreting.

What does it mean to describe? To say what happened, reporters have to draw on the language resources at hand. They tend to rely on standard wording, and some newspapers publish columns and news radio programs air commentaries that reinforce the standard. Journalists rarely make up new words but do pick up newly popular terms and phrases. Emerging trends-from "crime waves" throughout press history to so-called "metrosexuals" of the 1990s and the mistaken prevalence of "sexting" among teens of the 2000 s - need only exist in sources' imaginations first to enter the vocabulary of news and then into commonsense reality (Juntunen \& Väliverronen, 2010). Philosophers and historians of science have debated in- conclusively how much the limits of available language narrow or constrain what scientists can conceive (Mulkay, 1979). Journalists trade less often at the cutting edges of knowledge, but their use of buzzwords can produce misleading descriptions.

The way journalists learn their craft imposes another limitation. Through responding to the reporter's work, demanding revisions, and cutting out all or part of a story, editors communicate the acceptable limits of description. The process, called literary reason, permeates how journalists translate their work into stories (Knorr-Cetina, 1981). The routine tasks and processes of journalism require practical reason. Reporters look for scoops and exclusives to stand out on the job, using indexical reason, the clues to mark and sort experiences and discern what matters. Using analogical reason, they emulate models of successful reporting and seek familiar parallels to cover unfamiliar occurrences. Relying on socially situated reason, they respond to economic rewards, interpersonal relationships, and external and public demands and resources. And they do all four while defending journalism as a distinct occupation, employing symbolic reason. All five kinds of reasoning behind news description shift the emphasis onto journalists.

The shift leads to constructionism, because journalists' reason is constructing news. In a fundamental difference from realism, constructionism assumes that knowledge of an objective social-world-out-there does not accumulate. Practitioners like journalists instead construct facts and truth, connected to objects in the world but following social processes. Journalism has a productive quality that social constructionism brings into relief, renewing an older meaning of the word fact, which comes from the Latin facere, to make.

A concrete example of that construction in action is the surprising notion that statistics "makes" people (Hacking, 1990). Two centuries ago, Europeans considered chance little more than a vulgar superstition. Well-informed society thought that events grew out of a set of previous conditions as a result of particular causes. But in the nineteenth century, enumeration of everything expanded, and governments as well as other observers discovered patterns in occurrences like crimes and suicides. The new science of statistics found that human behavior occurs along a bell curve. Its normal distribution indicates that, far from superstition, chance reveals a picture of the aberrant (at the extremes) but also the normal person (at the center of the curve). By defining outliers, governments and institutions can take measurements of those at the extreme edges of society, plan ways to intervene in their lives, and track the changes that result. No matter the source, statistics feed back into society, defining what people are, and so statistics make people.

The same applies to news. Although journalists avoid thinking of themselves as agents of social con- 
trol, their reporting furthers institutional power over those at the social margins. News tends to emphasize occurrences at the far reaches of society, among those who strayed into crime or heroism, became or stood up against employers, faced accidental calamity or triumph, or came into or fell from political leadership. The outliers can define and reiterate the center of things, without actually pointing to the norms, through a process called simultaneous contrast (Barnhurst, 2007), in which saying one thing implies its opposite (as saying black brings to mind non-black things). Journalists consider covering marginal groups a type of progressive intervention for the downtrodden, but it does the opposite because pointing to the fringes reinforces the center. Journalism from newsrooms to websites creates models of personal identity and society (Barnhurst \& Nerone, 2001), and so news makes people. When the people learn from news how others like them behave and how their society works and then act on that learning, the news has helped make them into who they are.

Social constructionism has faced a strong reaction. Historian of science lan Hacking says that "a great fear of relativism" is one thing at work. "What are we afraid of?" he asks (Hacking, 2000, p. 4). If social interaction constructs everything, then nothing remains solid or secure, and "any opinion is as good as any other." But no one has seriously proposed that everything is constructed. Societies create three types of constructions: objects (including persons, such as women refugees), ideas (including time periods or qualities such as kindness), and something else called elevator words. Words like facts and truth occupy a higher (elevator) level because they try to say something about what the world is like, not what is in the world. Elevator words have two peculiar qualities: "First, they tend to be circularly defined," deriving their meaning from each other (as in the relation of facts to truth), and second, they "have undergone substantial mutations of sense and value" (Hacking, 2000, p. 23). The angry responses to social constructionism rely heavily on elevator words.

Historian Robert Darnton, who had a brief career in journalism, was among the first to apply constructionist views to journalism, concluding that reporters "bring more to the events they cover than they take away from them" (Darnton, 1975, p. 192). Stuart Hall and his co-authors from cultural studies examined British news and found that the "media define for the majority of the population what significant events are taking place" (Hall, Critcher, Jefferson, Clarke, \& Roberts, 1978, p. 57). The next two decades of critical scholarship sustained their views (see, e.g., Hartley, 1996; Esch, 1999). In practice, constructionism finds easy evidence in journalism. In a 1920s scandal in the news, prominent New York socialite Leonard Rinelander tried to annul his marriage to Alice Beatrice Jones, a working-class girl from New Rochelle (Lewis \& Ardizzone,
2001). The case turned on whether Leonard knew Alice's race, and journalists constructed Alice's race so that, in their reporting, she looked darker the more the outcome of the trial seemed to prove that she was, indeed, what then passed for "colored". Constructionists do not doubt that Alice herself existed but instead reveal how her existence took on differences according to the reporters' expectations. The journalists do not construct Alice in a concrete sense, but that sense is trivial. To say "Alice existed" has little meaning without referring to her skin color and the debate over racial identity that surrounded her body. The question was, which Alice existed, a white or a "colored" one?

Some journalists do acknowledge the role of reporters and news organizations in the construction of events. Essayist and filmmaker Nora Ephron told the story of standing outside, waiting and waiting for things to start, back when she was a young reporter for the New York Post. When the New York Times reporters arrived, the activity would begin, and she would stand there wondering, "How do they always know when an event will really start?" (Ephron, 2001, November 30$)$. Other reporters tell similar experiences, if not for attribution. In our interview, one reporter working in the New York Times Washington bureau during the presidency of the first George Bush witnessed reporters in the office receive advance warning that the Gulf conflict was going to begin in a few hours. Instead of saying whether or when the war would start, the tipster just suggested the Times reporters put off going to dinner for a couple of hours. While journalists from lesser news organizations went to eat as usual, the Times reporters stayed behind and got the story. The process reiterated another constructed dimension of news by reinforcing the preeminent position of the Times in defining U.S. events.

Constructionism provides another explanation for changes in the "what" of news during the twentieth century. After succumbing to propaganda in World War I and after conceding to McCarthyism at midcentury, journalists did not take opposite tacks. Despite the superficial contradiction-toward events in the former case, toward explanation in the latter-both responses to the crises produced similar results. Journalists responded by reasserting their power over news itself. They took a central position in public discussion by playing the role of moderators and facilitators for correcting the ills of political life. Instead of being victims of their economic conditions and professional competition, journalists participate in social and political power, because they build useful knowledge and because they engage in practices that define what is, what is known (or knowable), and what matters. Every member of a society does the same, but journalists can have a greater reach. Journalists' definitions reinforce their professional standing and put them on cultural par with those who occupy posts in the formal structures 
of government and business. The cultural view undermines any naïve claim of journalists' merely covering events "realistically".

But journalists take a humble, realist stance when asked. They see themselves doing the labor of events and facts in search of truth. Sociology reveals the connection of that labor to news economics and to professional status. Cultural scholarship dismantles the basic supports for realist observation and description, showing how distinctions between event-centered and explanatory news collapse when viewed through the power journalists were gaining either way. Whatever view one finds persuasive, a dramatic change has occurred in the "what" of news, the basic stuff of journalism or epistemology of their making things known. Journalists and the attentive public feel inundated by information, but news reports include fewer events, no matter how one measures them. The incongruity between beliefs in the glut of news events and the evidence of their decline exposes a misapprehension among journalists about their work. Audiences seemed able to adapt, riding on the waves of change in receiving news, but journalists in practice pushed back, returning to older patterns instead of reassessing facts and truth. Their retrenchment distanced news from the new paradigm of the digital era.

of course "journalists" here extends beyond individual reporters and editors, to the occupation of journalism, the print, broadcast, and digital industries that trade in news, and the systems of regulation surrounding public information and intellectual property. The individual journalist lives enmeshed in a surrounding society that expects journalism to be realist. That is one reason that mainstream U.S. journalism found itself in trouble in the new century. Events declined in news content just as the reading public gained access to more sources of news, eroding the credibility of journalism. The social world shifted at the end of the twentieth century, trapping journalists in realist expectations just at the time when they needed another perspective. And so the woes of American journalism express something deeper than trade and market competition, a problem of epistemology going back to the foundation of realist news.

\section{Acknowledgements}

This essay is a concise rendering of one part from a book manuscript in progress, Interpretive News. It looks back on more than a dozen studies during three decades spent researching the transformations of U.S. news in the twentieth century. The author wishes to thank the research assistants, students, and colleagues who provided feedback during those studies, which acknowledge individuals contributing to each project. More information is available at www.uic.edu/ $\sim$ kgbcomm/longnews.

\section{References}

Allen, F. L. (1922). Newspapers and the truth. Atlantic Monthly, January, 44.

Alterman, E. (2003). What Liberal Media? The Truth about Bias and the News. New York: Basic Books.

Barnhurst, K. G. (2002). News geography and monopoly: The form of reports on U.S. newspaper internet sites. Journalism Studies, 3(4), 477-489.

Barnhurst, K. G. (2003). The makers of meaning: National Public Radio and the new long journalism, 1980-2000. Political Communication, 20(1), 1-22.

Barnhurst, K. G. (2007). Visibility as Paradox: Representation and Simultaneous Contrast. In K. G. Barnhurst (Ed.), Media/Queered: Visibility and Its Discontents (pp. 1-20). New York: Peter Lang.

Barnhurst, K. G. (2010). Technology and the changing idea of news: 2001 U.S. Newspaper content at the maturity of Internet 1.0. International Journal of Communication, 4, 1082-1099.

Barnhurst, K. G. (2012). The Content of Online News in the Mainstream U.S. Press, 2001-2010. In S. Jones (Ed.), Communication @ the Center (pp. 231-253). New York: Hampton Press.

Barnhurst, K. G. (2013). Newspapers experiment online: Story content after a decade on the web. Journalism, 14(1), 1-19.

Barnhurst, K. G., \& Mutz, D. C. (1997). American journalism and the decline of event-centered reporting. Journal of Communication, 47(4), 27-53.

Barnhurst, K. G., \& Nerone, J. (2001). The Form of News: A History. New York: Guilford.

Boyle, E. H., \& Hoeschen, A. (2001). Theorizing the form of media coverage over time. The Sociological Quarterly, 42(4), 511-527.

Casey, R. D. (Ed.) (1963). The Press in Perspective. Baton Rouge: Louisiana State University Press.

Darnton, R. (1975). Writing news and telling stories. Daedalus, 104(2), 175-194.

Dewey, J. (1927). The Public and Its Problems. New York: Holt, Rinehart, and Co.

Donovan, R. J., \& Scherer, R. (1992). Unsilent Revolution: Television News and American Public Life. New York: Cambridge University Press.

Ephron, N. (2001, November 30). Telling a Story (speech). Narrative Journalism Conference, Harvard University, Cambridge, Massachusetts.

Esch, D. (1999). In the Event: Reading Journalism, Reading Theory. Stanford, CA: Stanford University Press.

Feinberg, J. (2009). How framing influences citizen understanding of public issues: An interview with Shanto lyengar. FrameWorks, March 2009. Retrieved from www.frameworksinstitute.org/assets/ files/iyengarinterview2009.pdf

Feldman, S. M. (2008). Free Expression and Democracy in America: A History. Chicago: University of Chicago Press. 
Fishman, M. (1980). Manufacturing the News. Austin: University of Texas Press.

Fuller, J. (2010). What Is Happening to News: The Information Explosion and the Crisis in Journalism. Chicago: University of Chicago Press.

Gitlin, T. (Ed.) (1987). Watching Television: A Pantheon Guide to Popular Culture. New York: Pantheon.

Goldstein, T. (Ed.) (1989). Killing the Messenger: 100 Years of Media Criticism. New York: Columbia University Press.

Griffith, R. (1987). The Politics of Fear: Joseph $R$. McCarthy and the Senate. Amherst: University of Massachusetts Press.

Hacking, I. (1990). The Taming of Chance. Cambridge: Cambridge University Press.

Hacking, I. (2000). The Social Construction of What? Cambridge: Harvard University Press.

Hall, S., Critcher, C., Jefferson, T., Clarke, J., \& Roberts, B. (1978). Policing the Crisis: Mugging, the State, and Law and Order. New York: Holmes and Meier.

Hartley, J. (1996). Popular Reality: Journalism, Modernity, Popular Culture. London: Arnold.

Hellmann, J. (1981). Fables of Fact: The New Journalism as New Fiction. Urbana: University of Illinois Press.

Irwin, W. (1969). The American Newspaper. Ames: Iowa State University Press.

lyengar, S. (1991). Is Anyone Responsible? How Television Frames Political Issues. Chicago: University of Chicago Press.

Juntunen, L., \& Väliverronen, E. (2010). Politics of sexting: Re-negotiating the boundaries of private and public in political journalism. Journalism Studies, 11(6), 817-831.

Knorr-Cetina, K. (1981). The Manufacture of Knowledge: An Essay on the Constructivist and Contextual Nature of Science. Oxford: Pergamon.

Kuhn, T. S. (1996). The Structure of Scientific Revolutions. Chicago: University of Chicago Press.

Lakatos, I. (1974). Falsification and the Methodology of Scientific Research Programmes. In I. Lakatos \& A. Musgrave (Eds.), Criticism and the Growth of Knowledge (pp. 91-196). New York: Cambridge University Press.

Lewis, E., \& Ardizzone, H. (2001). Love on Trial: An American Scandal in Black and White. New York: Norton.

Lippmann, W., \& Merz, C. (1920, August 4). A test of news. The New Republic, 2-3.

Mears, W. R. (2009). Finding news despite the noise. Journalism Studies, 10(3), 423-426.

Mock, J. R., \& Larson, C. (1968). Words that Won the War: The Story of the Committee on Public Relations, 1917-1919. New York: Russell and Russell.

Molotch, H., \& Lester, M. (1974). News as purposive behavior: On the strategic use of routine events, accidents, and scandals. American Sociological Review, 38(1), 101-112.
Mott, F. L. (1952). The News in America. Cambridge: Harvard University Press.

Mulkay, M. (1979). Science and the Sociology of Knowledge. London: Allen and Unwin.

New York Times. (2004, May 26). Times and Iraq. New York Times. Retrieved from www.nytimes.com/ 2004/05/26/international/middleeast/26FTE_NOTE .html

Nordenson, B. (2008). Overload! Columbia Journalism Review, 2008(November-December). Retrieved from www.cjr.org

Pew Research Center. (2006, July 30). Online papers modestly boost newspaper readership. Pew Research Center. Retrieved from www.people-press. org/2006/07/30

Project for Excellence in Journalism (PEJ). (2006). Network TV. The State of the News Media 2006. Retrieved from www.stateofthemedia.org/2006

Purcell, K., Rainie, L., Mitchell, A., Rosenstiel, T., \& Olmstead, K. (2010, March 1). Understanding the participatory news consumer. Pew Research Center. Retrieved from www.journalism.org/2010/03/01/ understanding-participatory-news-consumer. See also www. pewinternet.org/Reports/2010/Online-News. aspx

Rainey, J. (2006, March 13). More news outlets, fewer stories: New media 'paradox'. Los Angeles Times. Retrieved from http://articles.latimes.com/2006/ mar/13/nation/na-news13

Ranney, A. (1983). Channels of Power: The Impact of Television on American Politics. New York: Basic.

Reese, S. D., \& Ballinger, J. (2001). The roots of a sociology of news: Remembering Mr. Gates and "Social control in the newsroom". Journalism and Mass Communication Quarterly, 78(4), 641-658.

Regan, T. (2000). Technology is changing journalism just as it always has. Nieman Reports, 54(4), 4-30.

Riffe, D., \& Budianto, A. (2001). The shrinking world of network news. International Communication Bulletin, 36(1-2), 18-35.

Rosenblum, M. (1981). Coups and Earthquakes: Reporting the World for America. New York: Harper and Row.

Rosenblum, M. (1993). Who Stole the News? Why We Can't Keep Up with What Happens in the World and What We Can Do about It. New York: J. Wiley.

Rosenthal, J. (2004, August 8). What to do when news grows old before its time. New York Times. Retrieved from www.nytimes.com/2004/08/08/opinion/thepublic-editor-what-to-do-when-news-grows-oldbefore-its-time.html

Ross, S. S. (1998). Journalists' Use of Online Technology and Sources. In D. L. Borden \& K. Harvey (Eds.), The Electronic Grapevine: Rumor, Reputation, and Reporting in the New Online Environment (pp. 143160). Mahwah, NJ: Erlbaum.

Schudson, M. (2001). The objectivity norm in American 
journalism. Journalism, 2(2), 149-170.

Shafer, J. (2009, August 27). Ink hole. Slate Magazine. Retrieved from www.Slate.com/id/2226419

Sinclair, U. (1936). The Brass Check: A Study of American Journalism (11th ed.). Pasadena: by the author.

Sproule, J. M. (1987). Propaganda studies in American social science: The rise and fall of the critical paradigm. Quarterly Journal of Speech, 73(1), 60-78.

Steele, C. A., \& Barnhurst, K. G. (1996). The journalism of opinion: Network coverage in U.S. Presidential campaigns, 1968-1988. Critical Studies in Mass Communication, 13(3), 187-209.

Vaihinger, H. (1968). The Philosophy of As if. New York: Barnes and Noble.

Walsh, M., \& Vivons, M. (2010, October 20). New sur- vey reveals extent, impact of information overload on workers (2010 international workplace productivity survey). LexisNexis. Retrieved from www. multivu.com

White, A. (1970). Truth. Garden City, NY: Anchor Books.

White, D. M. (1950). The 'gate keeper': A study in the selection of news. Journalism Quarterly, 27(4), 383396.

Williams, A. (2008, October 10). Overfeeding on information. New York Times. Retrieved from www.ny times.com/2008/10/12/fashion/sundaystyles/12ne ws.html

Winburn, J. (2003). Shop Talk and War Stories: American Journalists Examine Their Profession. New York: Bedford/St. Martin's.

\section{About the Author}

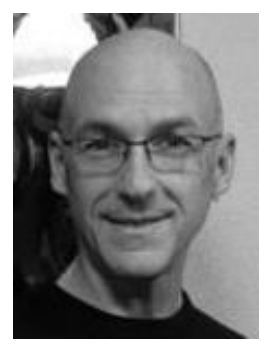

\section{Dr. Kevin G. Barnhurst}

Kevin G. Barnhurst is Professor and holds the Chair of Communication in the Digital Era in the School of Media and Communication, University of Leeds, UK. He is also Professor Emeritus in the Department of Communication at the University of Illinois at Chicago, USA. 